\title{
Studying and Detecting the Influences of the Solar Irradiance and Temperature Regarding the Characteristic of Photovoltaic at Al- Nasiriya City
}

\author{
Abdullh Saiwan Majli*, Satar Habib Mnaathr \\ Department of Electric and Electronic, College of Engineering, Thi Qar University, Iraq
}

Copyright $\mathrm{O} 2019$ by authors, all rights reserved. Authors agree that this article remains permanently open access under the terms of the Creative Commons Attribution License 4.0 International License

\begin{abstract}
Solar energy is obtainable in the earth as an unlimited source of clean energy. There is an increasing bearing in the carbon release in the world. There are two parameters mainly affect the efficiency of the solar system that are solar radiation and temperature. In this research, the Effect of the Solar Irradiance and Temperature on the Characteristic of Photovoltaic in Al-Nasiriya City is studied. PVsyst simulation facility is to be used for design and optimization. A computation has been conducted to verify the change in $i-v$ and $p-v$ characteristics of the system. The suggest model is based on a behavioral cell model for styling solar radiance to electricity transformation and to confirm the different factors assuming the solar PV system competence. The temperature and radiation data has been possessed from the position of Al-Nasiriya City in Iraq south.
\end{abstract}

Keywords Solar PV Cell, PVsyst Software, Efficiency, Solar Radiation, Cell Temperature

\section{Introduction}

A standout amongst the most potential sustainable power source found is sunlight based vitality. Sun oriented vitality is the brilliant warmth and light from the sun that has been utilized by people since antiquated occasions utilizing an extensive variety of advancements. One of the wide uses of sun oriented vitality is photovoltaic (PV). PV is the field of innovation and research identified with the utilization of sun oriented cells for vitality by changing over daylight specifically into power by the photovoltaic impact. Sunlight based boards; photovoltaic clusters and sun powered modules are made by gatherings of sun oriented cells. There are numerous innovations used to extricate the power from these characteristic assets. Additionally numerous elements are affecting to deliver the power from these common assets, for example, environmental temperature, weight, wind speed and climatic condition. Among sustainable power source assets, sunlight based vitality is the quickest development on the planet (at the rate of $20-25 \%$ every year) in many built up the creating nations over the most recent 20 years $[1,2]$. There are two sorts of technology utilize to change over the sun oriented vitality, for example, sunlight based warm and sun oriented cell. Sun based cell (PV) changes over the daylight into electrical vitality by the photovoltaic impact. Sun powered PV cell are comprised of semiconducting material which having PN intersection. Figure 1 demonstrates the photocurrent fundamentals of PV cells and its operation. To investigate the performance on the basis of change in i-v and $\mathrm{p}-\mathrm{v}$ characteristics of the PV system, PVsyst is a simulation program which is able to simulate both stands alone and grid connected PV systems [7]. It provides the design proposals (Area required, module size, inverter size etc.). PVsyst. It consists of input radiation units files of many locations in itself and can be import from NASA-SSE Worldwide [4,5]. PV units are the main power conversion unit system of a PV generator. The produce features of PV units depend on the cell temperature, solar radiation, and the output voltage that arrive from PV unit. Moreover, mathematical modeling of $\mathrm{PV}$ module is constantly refreshed to empower specialist to have a superior comprehension of its working [6]. 


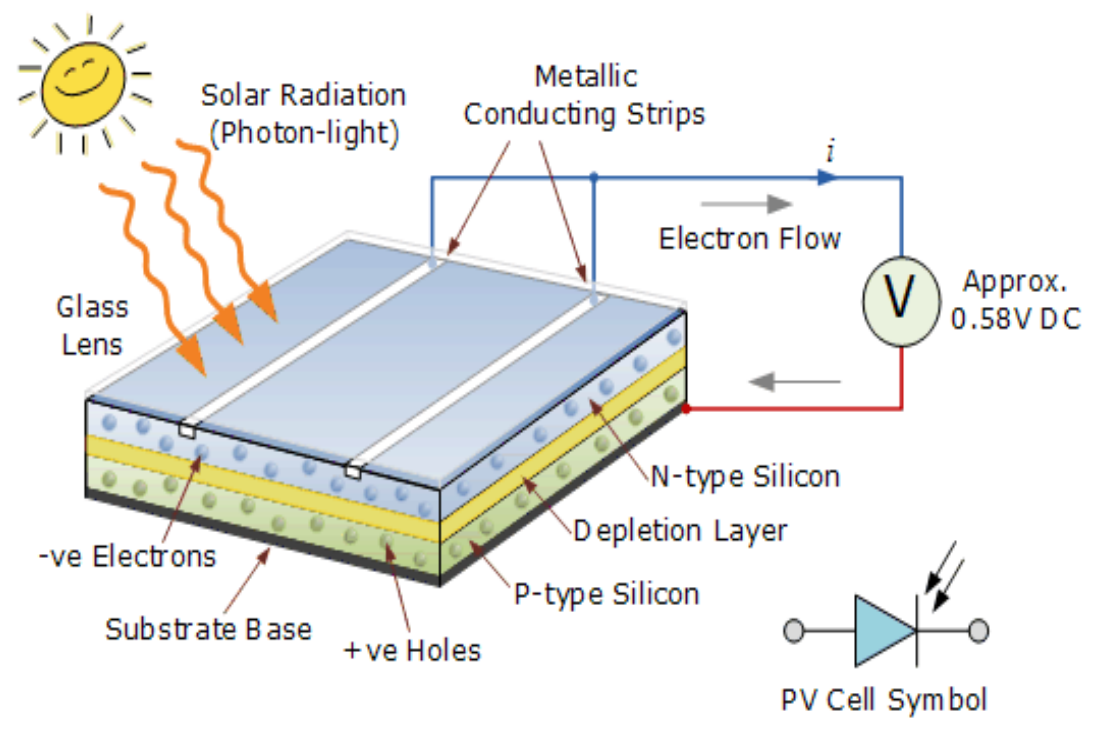

Figure 1. Photovoltaic Solar PV cell construction and operation [1]

Solar energy obtained from a solar PV cell is not constant all the time. Solar energy is influenced by outside conditions like sun based irradiance and temperature Solar irradiance and cell temperature are indicated out influence PV cell yield to a significantly more noteworthy degree than alternate conditions $[7,8]$. Besides, the measure of extricated control from a PV framework is an element of the PV cluster voltage and current set point. Because of these reasons expressed above, it is vital to augment the yield electric power accessible from the PV cell. As a matter of fact the sunlight based PV cell has nonlinear I-V and P-V qualities which is relies upon the irradiance and the working temperature additionally in load state of the cell $[8,12]$. The solar energy is availability varies widely with time. So, it is very necessary to make a complete utilization of solar energy in available time. For this purpose an improved PV module has been introduced which is the development of mathematical modeling of PV arrays. The objective is to validate the P-V \& I-V characteristics of practical solar PV arrays.

\section{PV Cell Modeling}

The sun based cell is the essential unit of a PV framework. Sunlight based Cell or Photovoltaic (PV) cell is a gadget that is comprised of semiconductor materials, for example, silicon, gallium arsenide and cadmium telluride, and so on that that converts sunlight immediately into electricity. The voltage of a sun based cell does not depend emphatically on the sun powered irradiance but rather depends fundamentally on the cell temperature. PV modules can be intended to work at various voltages by interfacing sun based cells in arrangement. At the point when sun powered cells ingest daylight, free electrons and openings are made at positive/negative intersections. On the off chance that the positive and negative intersections of sun based cell are associated with DC electrical gear, current is conveyed to work the electrical tools.

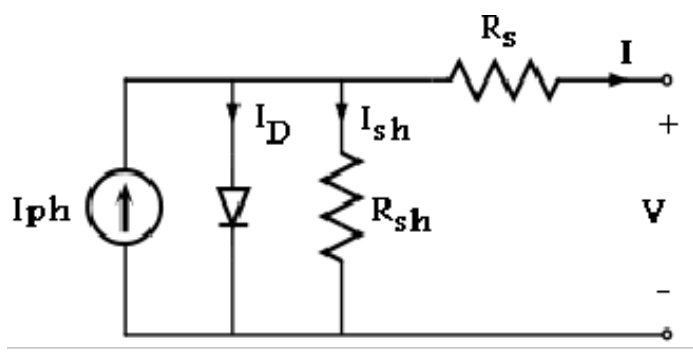

Figure 2. Communal model circuit of PV cell

The voltage-current distinctive formula of a solar cell [1], is given as:

$$
I=I_{p h}-I_{S}\left\{\exp \frac{q\left(V+I R_{S}\right)}{A \cdot K . T}-1\right\}-\frac{\left(V+I R_{S}\right)}{R_{S h}}
$$

Where IPH is photocurrent or a light-generated current, Tc is the cell's working temperature, the cell saturation of dark current is Is, and charge of electron $\mathrm{q}=1.6 \times 10-19 \mathrm{C}$, Boltzmann's constant $\mathrm{k}=1.38 \times 10-23 \mathrm{~J} / \mathrm{K}, \mathrm{A}$ is refer to perfect factor, the ideal factor $\mathrm{A}$ is based on $\mathrm{PV}$ technology [8Rs is a series resistance and Rsh is a shunt resistance. The output voltage of $\mathrm{PV}$ cell is a function of the photocurrent which at most specified by load current build on the solar irradiation level through the process. The open circuit voltage and short circuit current depend on parameters like solar irradiance and the temperature [11] as shown in equations 2 and 3 .

$$
\begin{gathered}
\mathrm{V}_{\mathrm{oc}=}=\frac{k T}{q} \ln \frac{I_{S c}}{I_{S}} \\
\mathrm{I}_{\mathrm{sc}}=\mathrm{bH}
\end{gathered}
$$

Where $\mathrm{H}$ is the incident light intensity and $\mathrm{b}$ is a constant depending on the properties of the semiconductor junction. 


\section{Research Procedure}

The efficiency of a solar PV plant is highly depends on the azimuth angle and tilt angle of PV modules. So these are adjusted in such a manner to get maximum irradiance from the sun and albedo factor taken for this study is 0.2 . Geographical location provides the (x,y,z) co-ordinates of a site that of a site that of is latitude, longitude and altitude which defines the position of a point on the earth and time zone[ 9,10$]$.

Meteo file includes complete information of geographical site parameters that is horizontal global, beam and diffusive irradiations, ambient temperature and wind velocity (If available).

Table 1. Location Details

\begin{tabular}{|c|c|}
\hline country & Iraq \\
\hline City & al-Nasiriyah \\
\hline Latitude & 31.1 \\
\hline Longitude & 46.1 \\
\hline Altitude & $9 \mathrm{~m}$ \\
\hline Time Zone & $3 \mathrm{hr}$ \\
\hline
\end{tabular}

Table 2. Technical details of the $60 \mathrm{~W}$ solar PV Panel

\begin{tabular}{|c|c|}
\hline Description & Si-Poly \\
\hline Model & $60 \mathrm{w}$ \\
\hline Model Dimension & $502 \times 1109 \mathrm{~mm}$ \\
\hline Model weight & $7.2 \mathrm{~kg}$ \\
\hline Open circuit voltage & $21.1 \mathrm{~V}$ \\
\hline Short circuit current & $3.8 \mathrm{~A}$ \\
\hline Voltage at peak power point & $17 \mathrm{~V}$ \\
\hline Current at peak power point & $3.53 \mathrm{~A}$ \\
\hline
\end{tabular}

Using the PVsyst the impact of temperature and irradiation on the power output of the system has been examined. In this work the special two model of the solar $\mathrm{PV}$ configuration with subsystem and tested.

In this model, $60 \mathrm{~W}$ solar panel makings data has been stabled to work the model. The outcomes have been explained in the figure 4 to 9 as Voltage Vs current and Voltage Vs Power. Thus, the PV cell current is robustly following on the solar radiation. In general, for a given sunlight based radiation, when the temperature of cell increases, the open circuit voltage Voc, drops somewhat, while the short out current increments. This conduct is validated and presented in Figure 10 to 15.

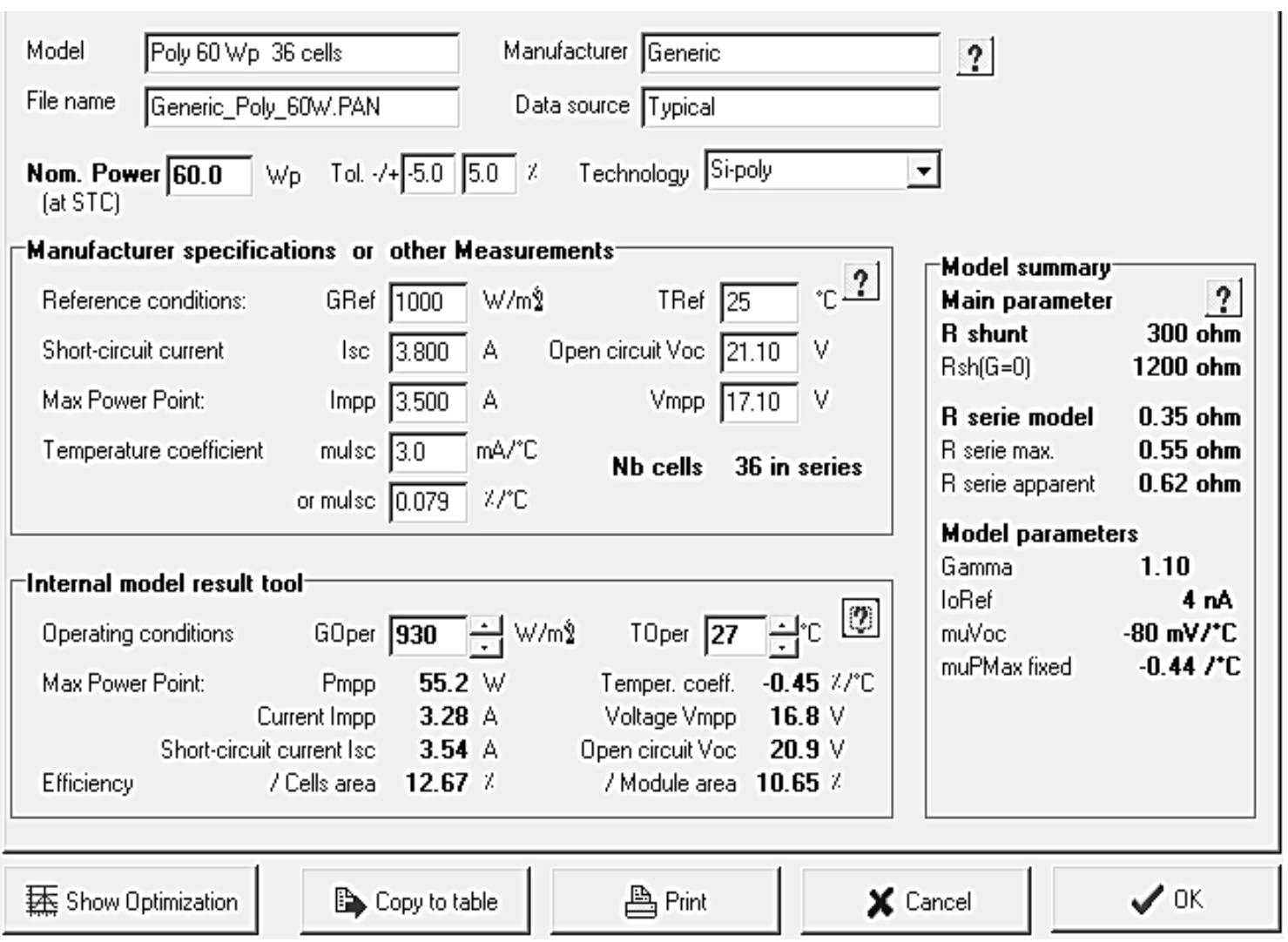

Figure 3. PV system model for solar PV system 
Temperature Regarding the Characteristic of Photovoltaic at Al- Nasiriya City

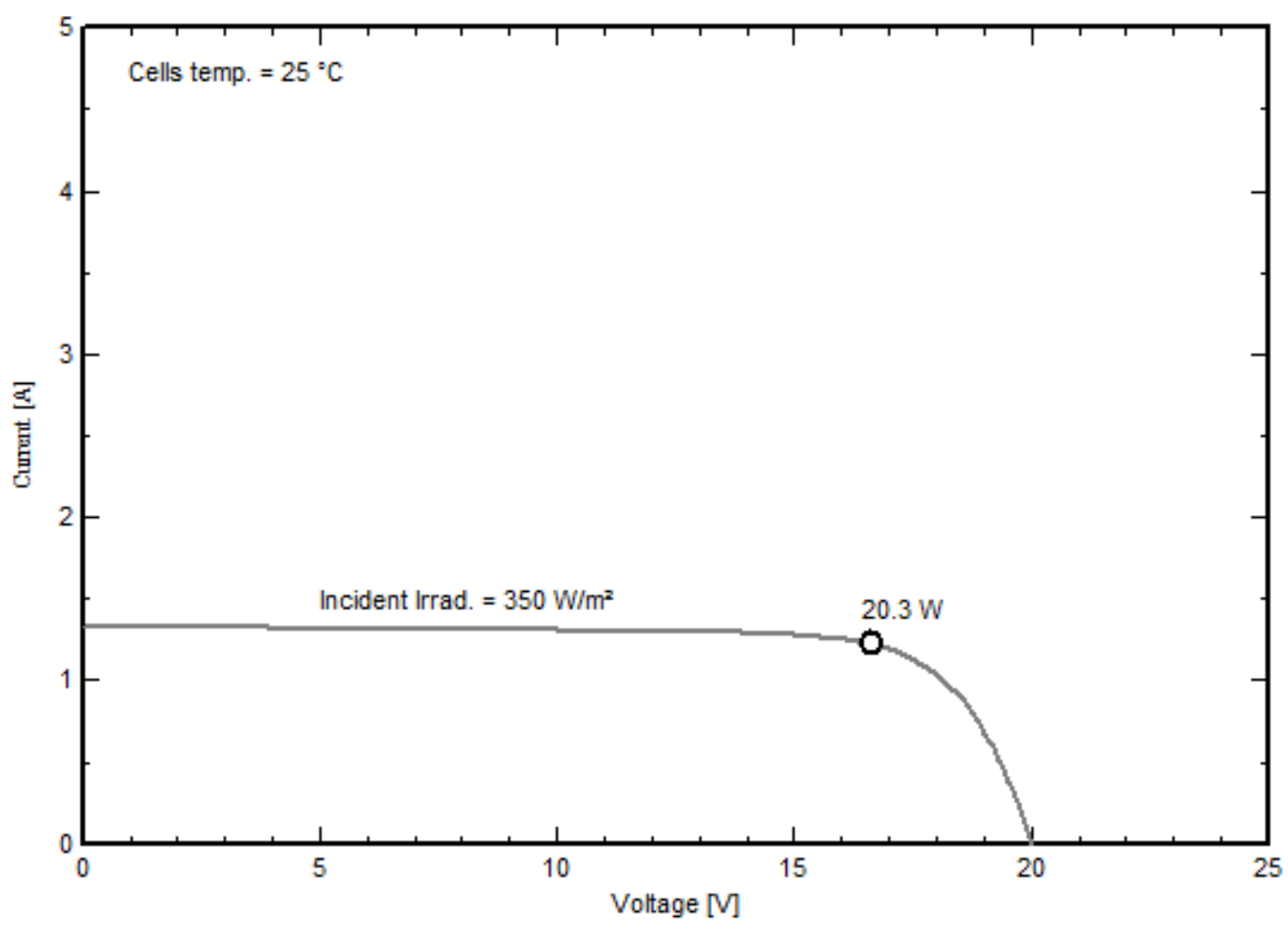

Figure 4. Current vs voltage, Temperature $25^{\circ} \mathrm{C}$ and Solar Radiation $350 \mathrm{~W} / \mathrm{m}^{2}$

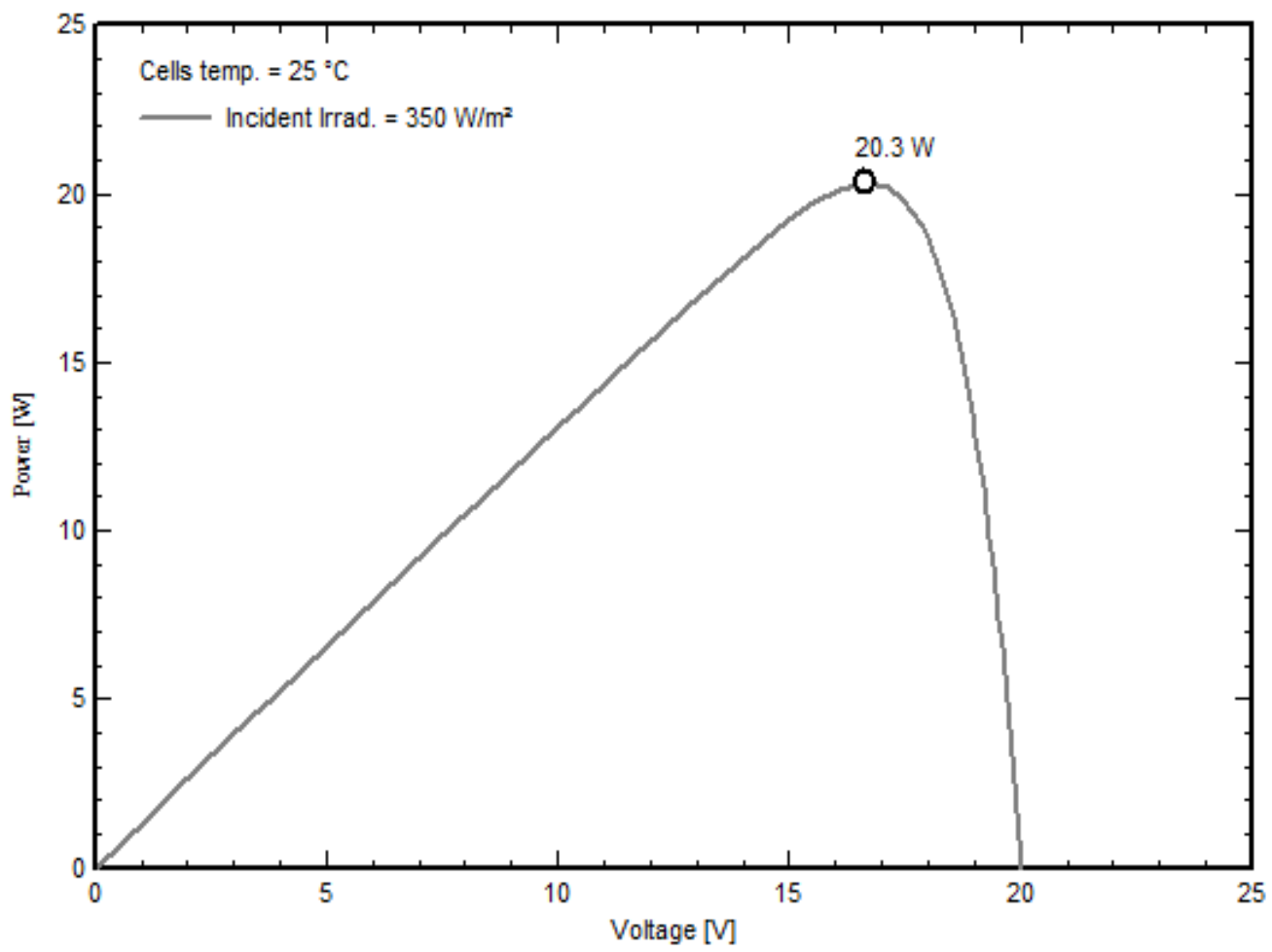

Figure 5. Power vs voltage, Temperature $25^{\circ} \mathrm{C}$ and Solar Radiation $350 \mathrm{~W} / \mathrm{m}^{2}$ 


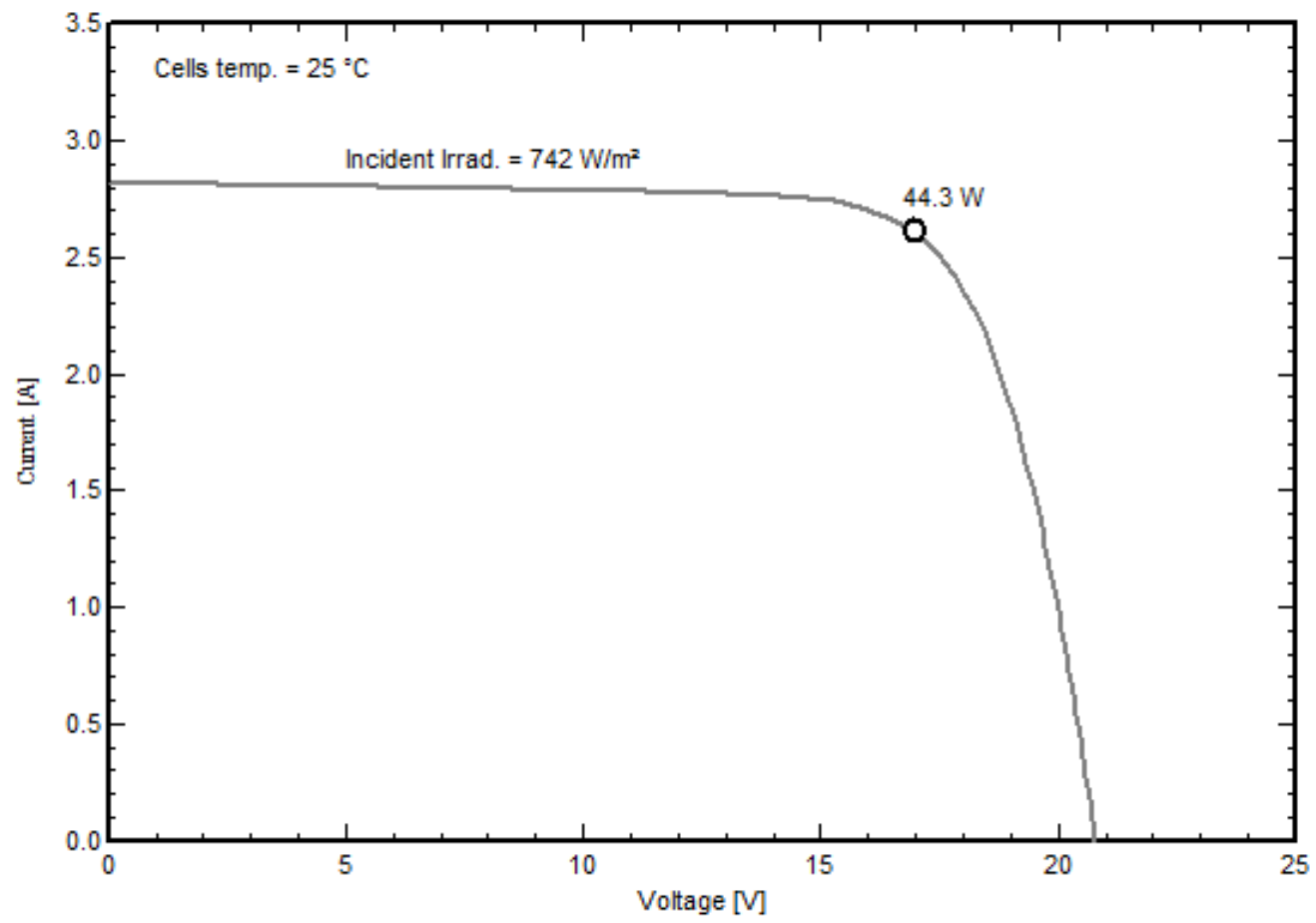

Figure 6. Voltage vs current, Temperature $25^{\circ} \mathrm{C}$ and Solar Radiation $742 \mathrm{~W} / \mathrm{m}^{2}$

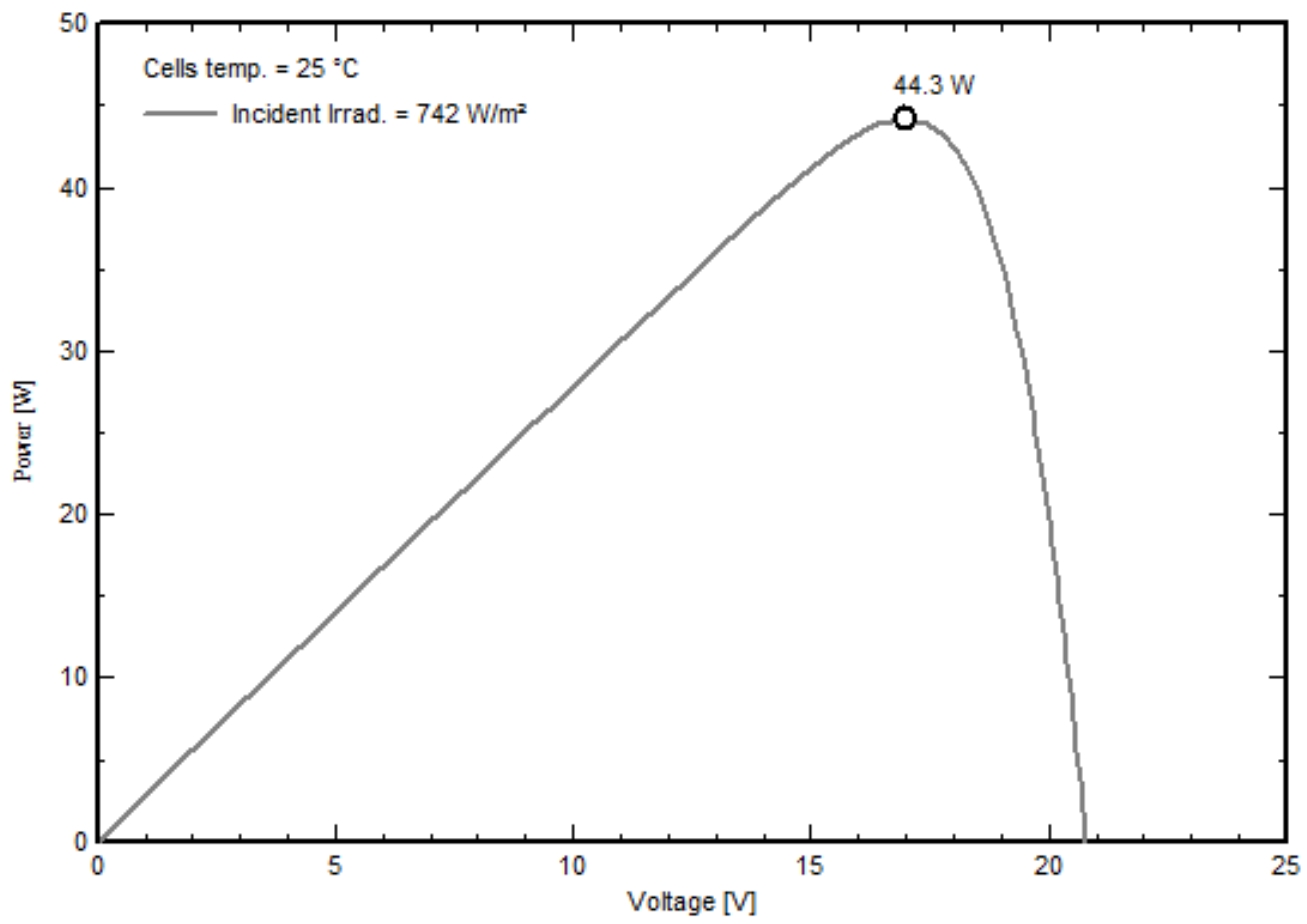

Figure 7. Power vs voltage, Temperature $25^{\circ} \mathrm{C}$ and Solar Radiation $742 \mathrm{~W} / \mathrm{m}^{2}$ 
Temperature Regarding the Characteristic of Photovoltaic at Al- Nasiriya City

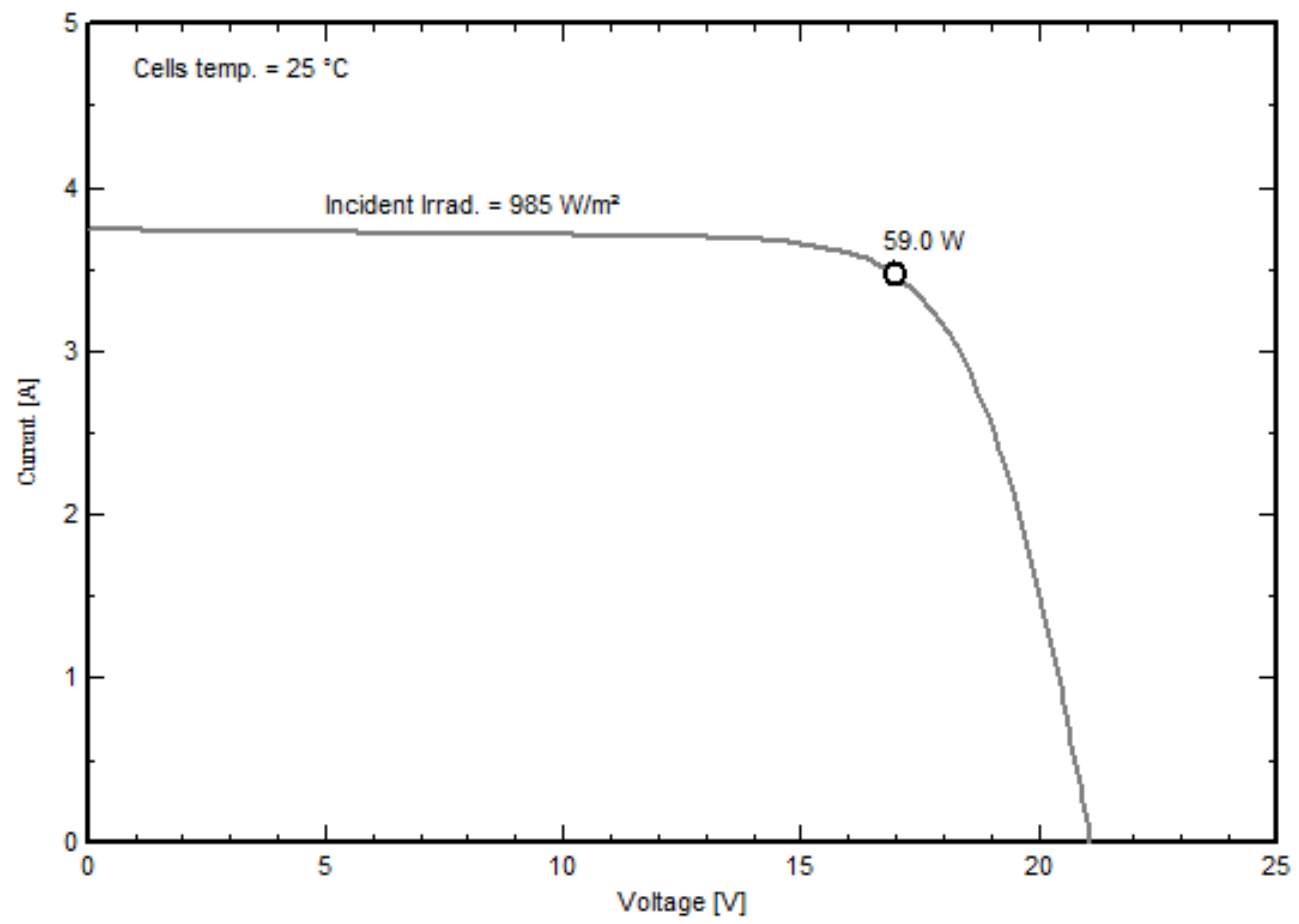

Figure 8. Voltage vs current, Temperature $25^{\circ} \mathrm{C}$ and Solar Radiation $985 \mathrm{~W} / \mathrm{m}^{2}$

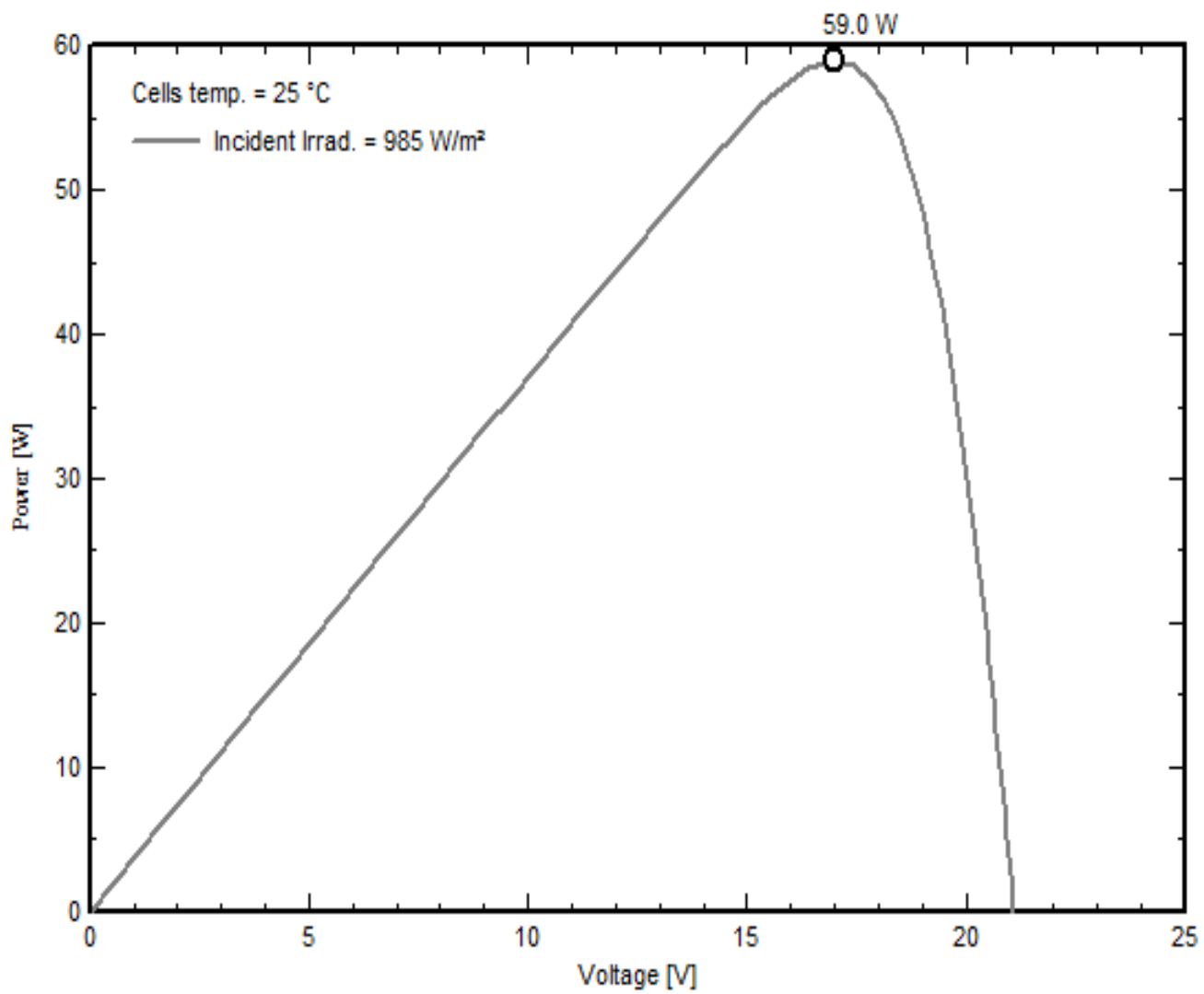

Figure 9. Power vs voltage, Temperature $25^{\circ} \mathrm{C}$ and Solar Radiation $985 \mathrm{~W} / \mathrm{m}^{2}$ 


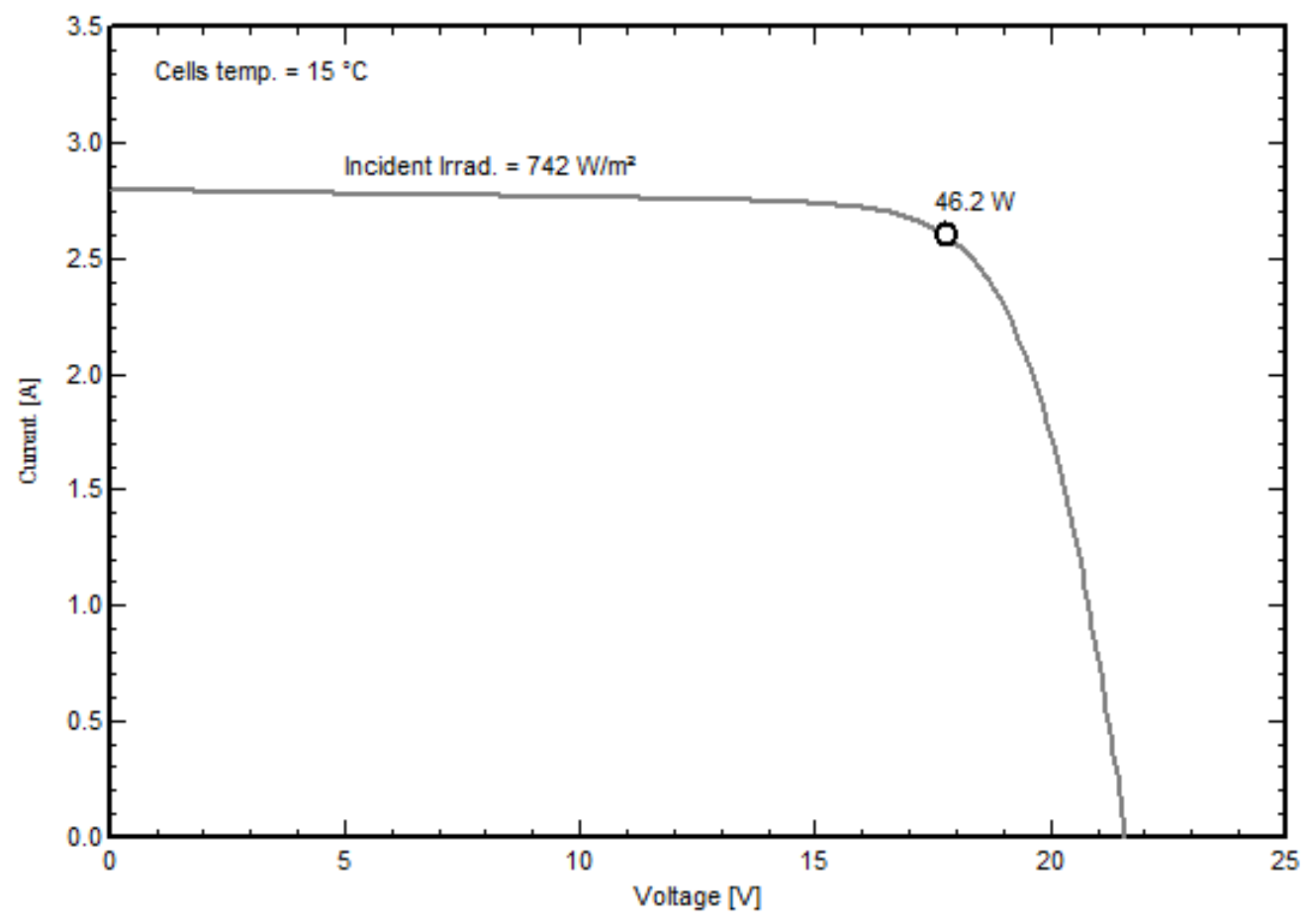

Figure 10. Voltage vs current, Solar Radiation $742 \mathrm{~W} / \mathrm{m}^{2}$, Temperature $25^{\circ} \mathrm{C}$

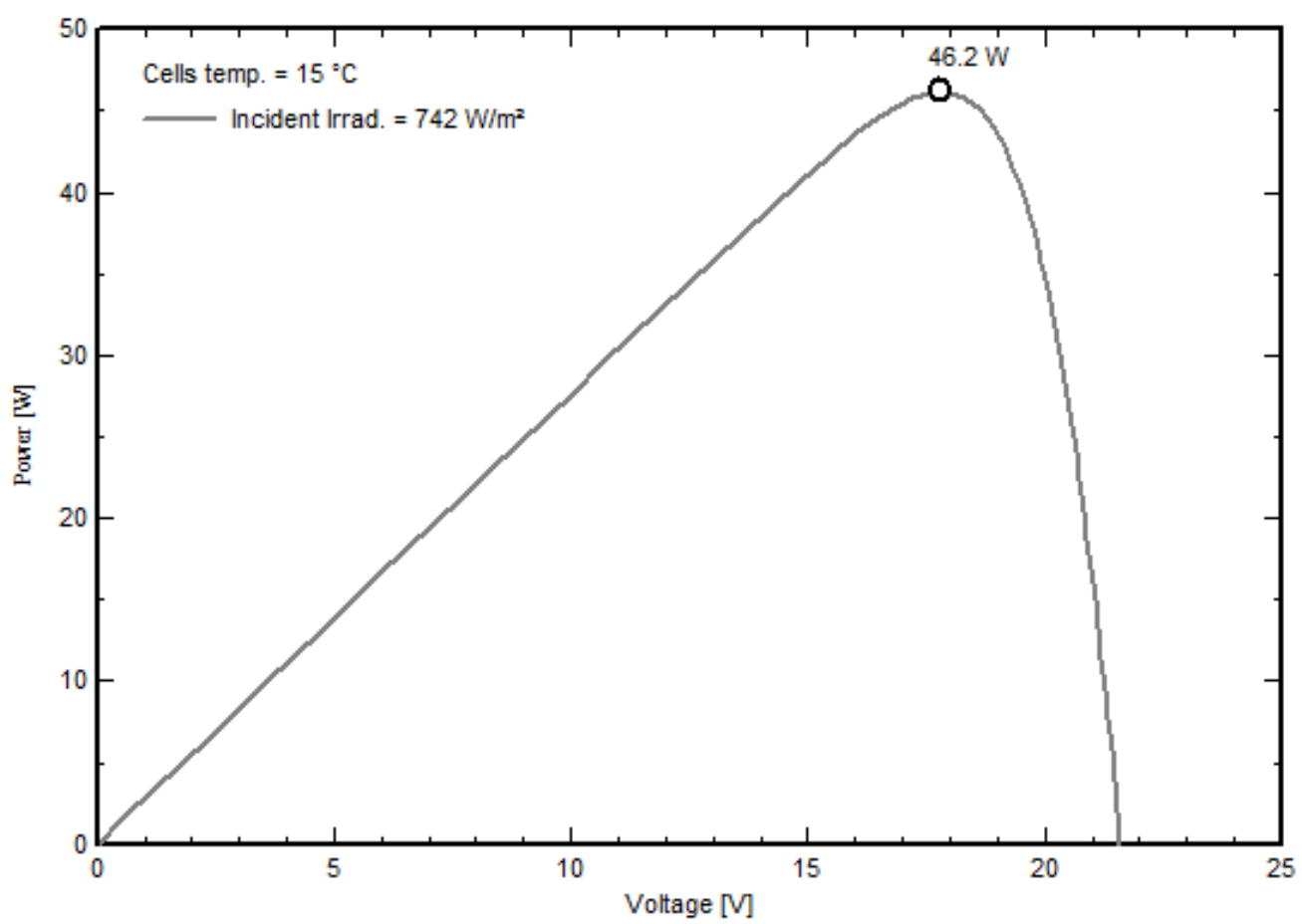

Figure 11. Power vs voltage, Solar Radiation $742 \mathrm{~W} / \mathrm{m}^{2}$, Temperature $25^{\circ} \mathrm{C}$ 
Temperature Regarding the Characteristic of Photovoltaic at Al- Nasiriya City

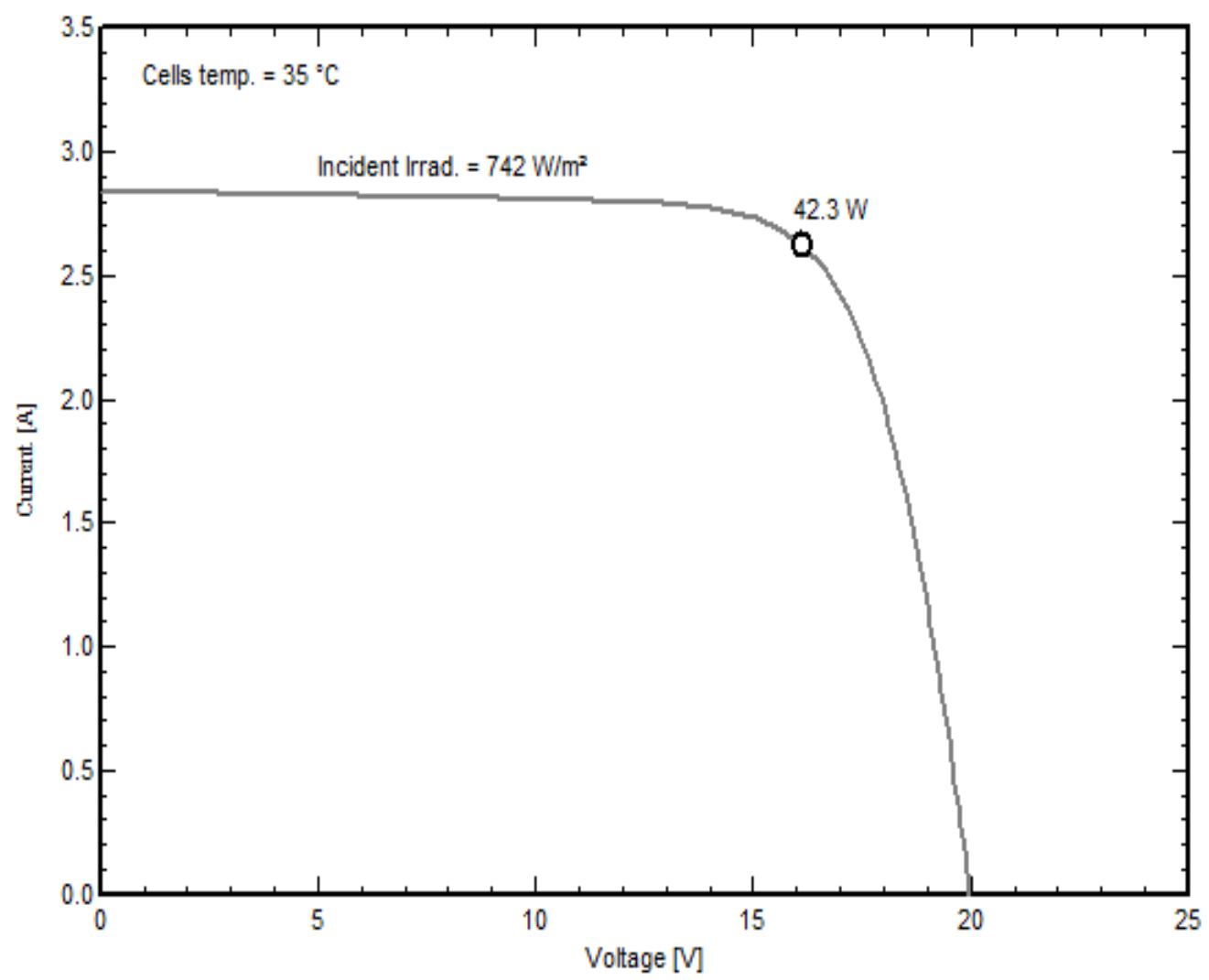

Figure 12. Voltage vs current, Solar Radiation $742 \mathrm{~W} / \mathrm{m}^{2}$, Temperature $35^{\circ} \mathrm{C}$

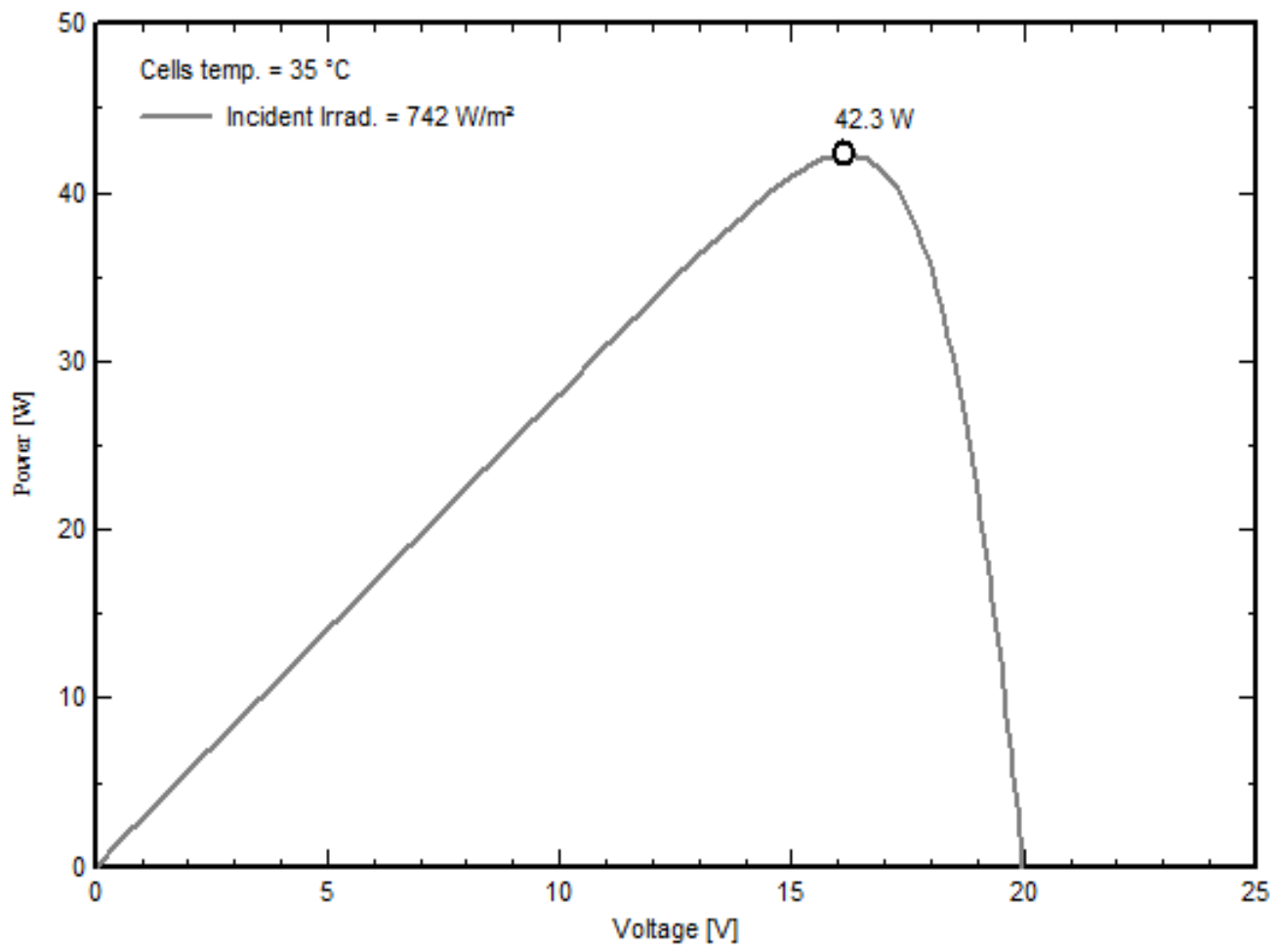

Figure 13. Power vs voltage, Solar Radiation $742 \mathrm{~W} / \mathrm{m}^{2}$, Temperature $35^{\circ} \mathrm{C}$ 


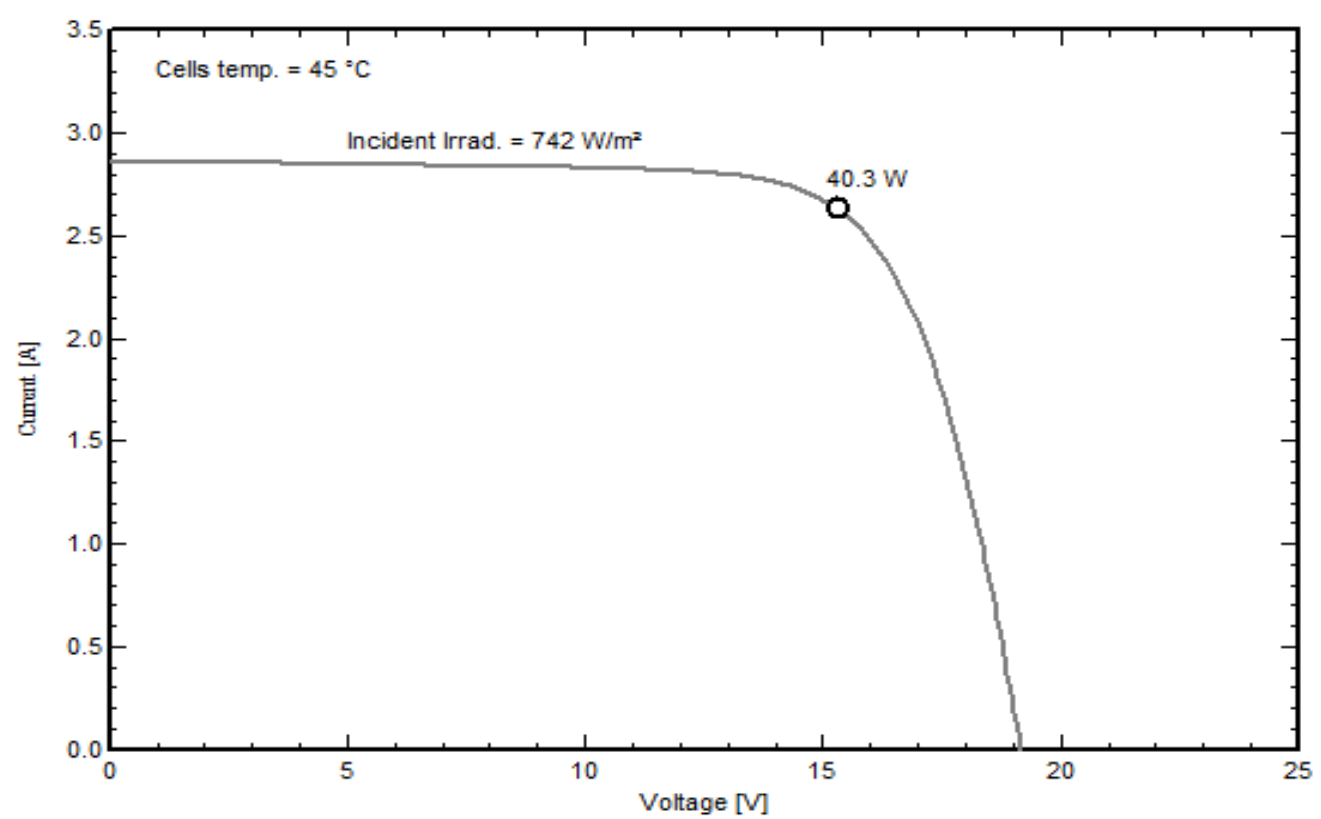

Figure 14. Voltage vs current, Solar Radiation $742 \mathrm{~W} / \mathrm{m}^{2}$, Temperature $45^{\circ} \mathrm{C}$

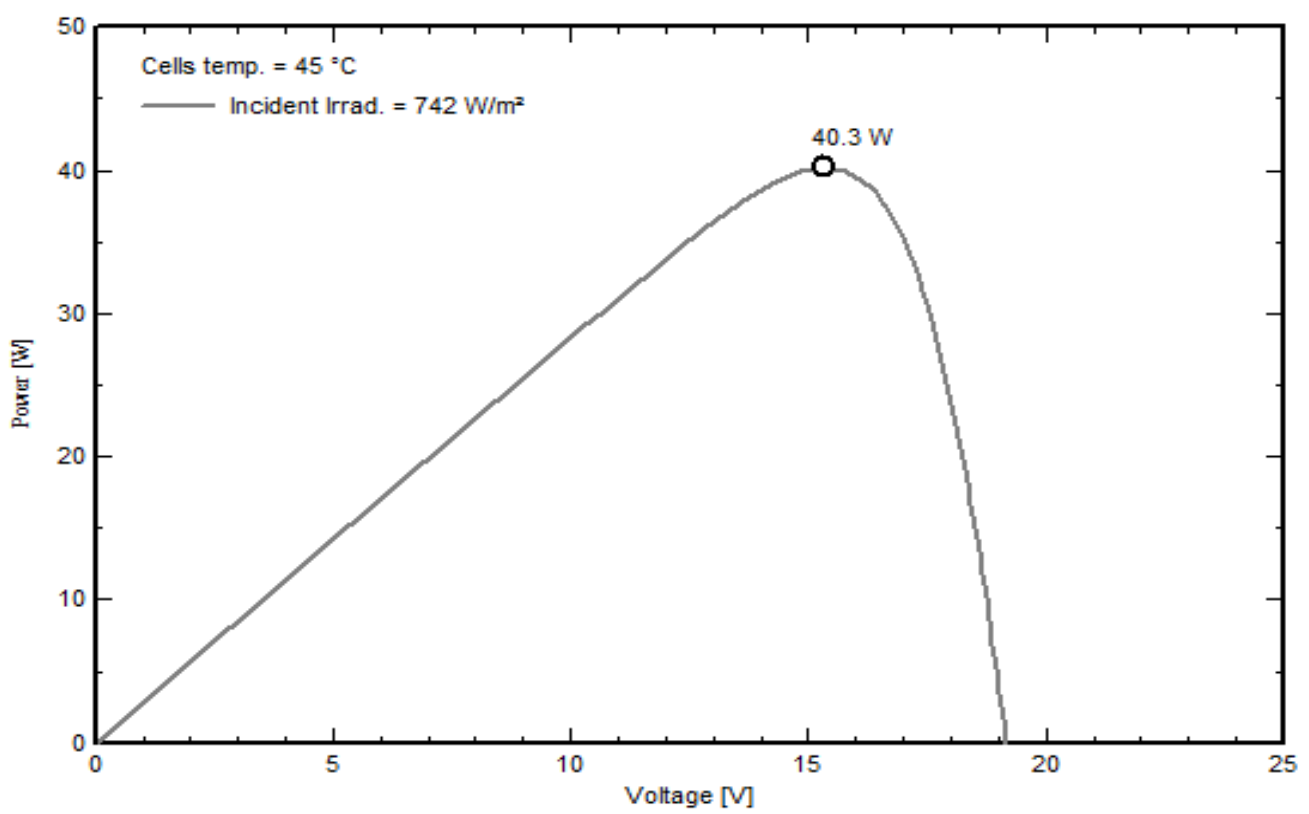

Figure 15. Power vs voltage, Solar Radiation $742 \mathrm{~W} / \mathrm{m}^{2}$, Temperature $45^{\circ} \mathrm{C}$ 


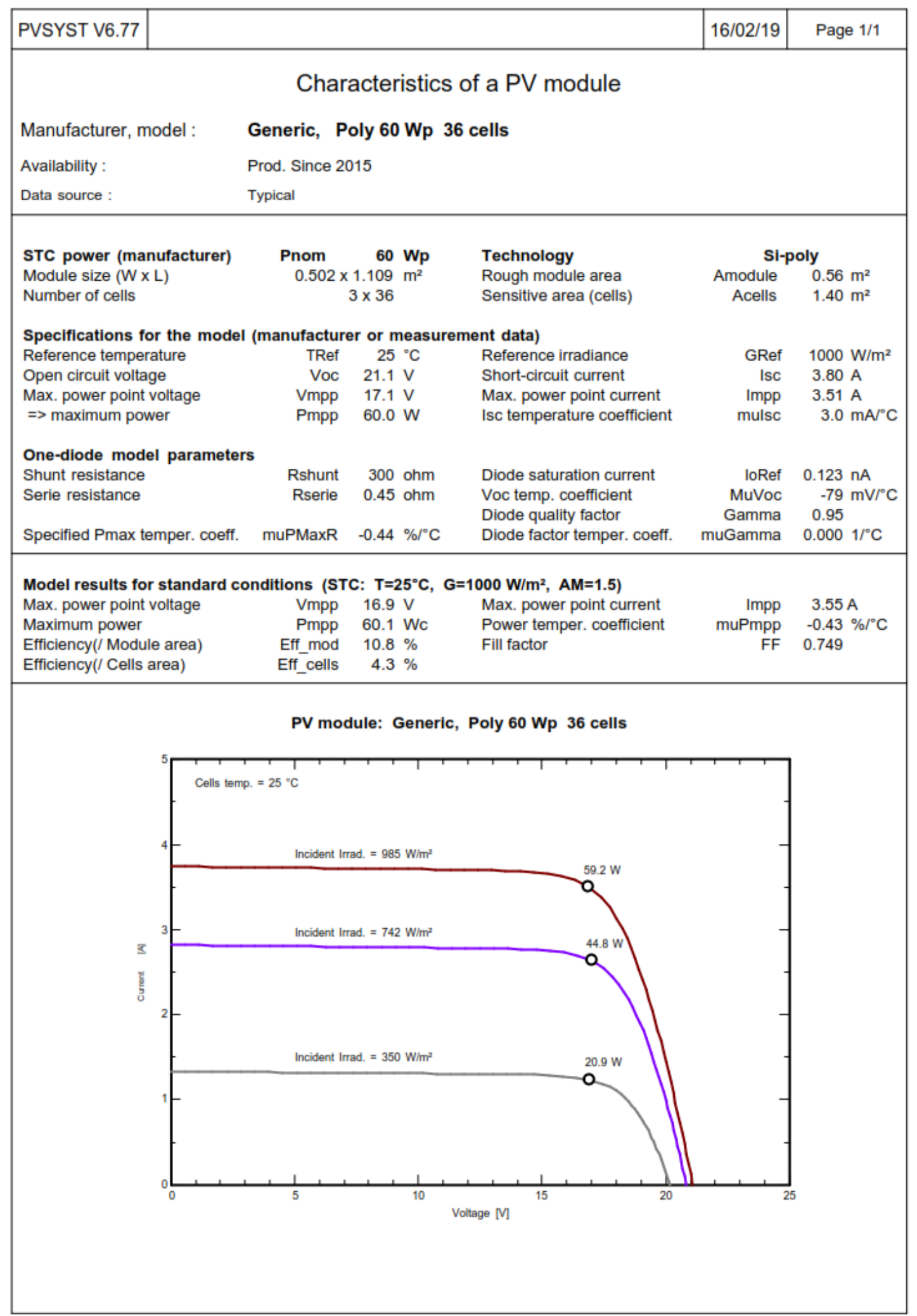

Figure 16. Shows the current versus voltage curve at various irradiance level

In the figure16, the V-I characteristics of previous sample at light intensities 350,742 , and $985 \mathrm{~W} / \mathrm{m}^{2}$ have been shown. As can be seen, V-I characteristics of solar cell vary under different levels of illumination. The measurements were performed at 25,35 , and $45 \mathrm{c}$ o temperature showed in figure 18 . 


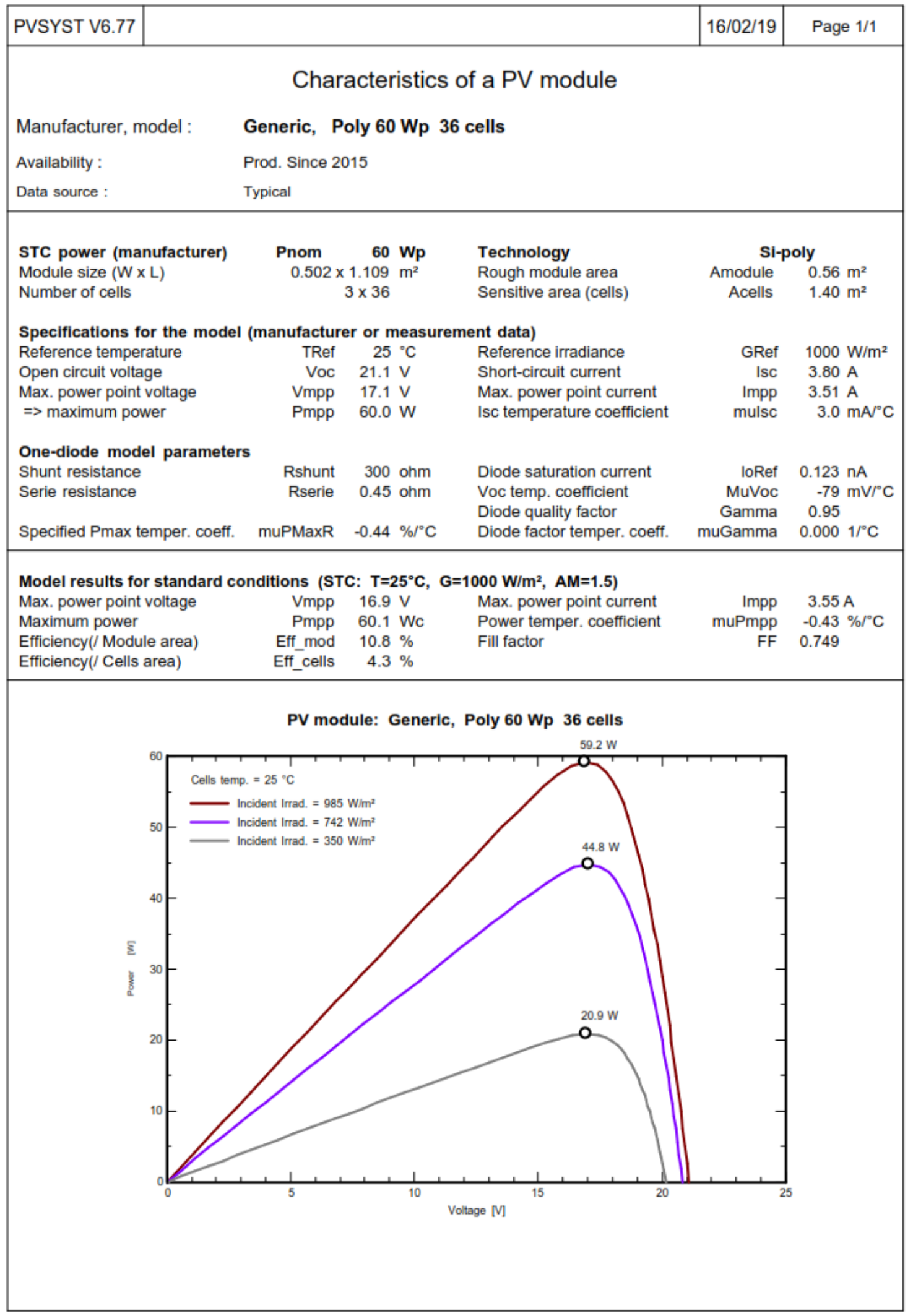

Figure 17. Shows the power versus voltage characteristics at three different irradiance levels 


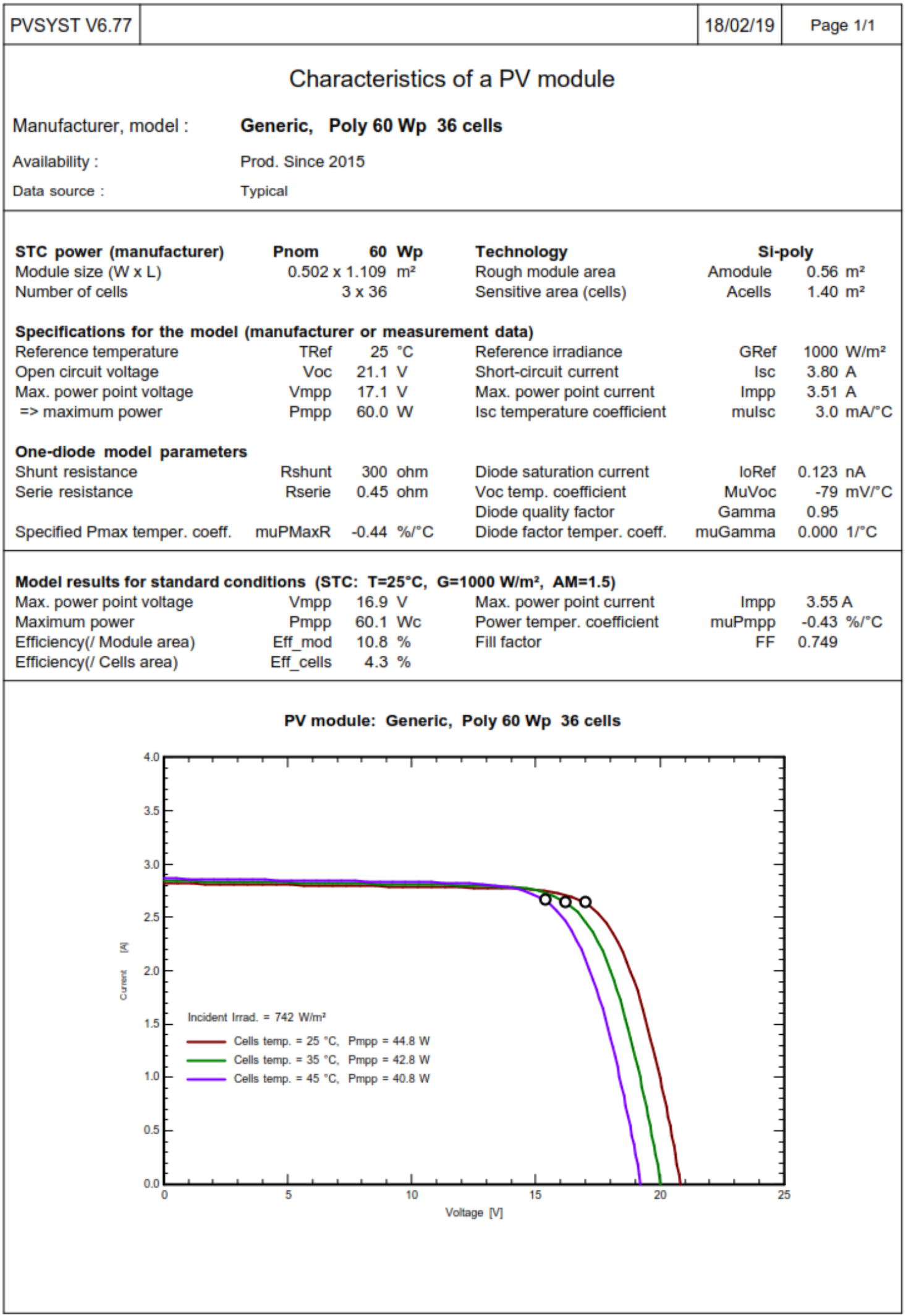

Figure 18. Shows how the I-V curve varies with varying temperature 


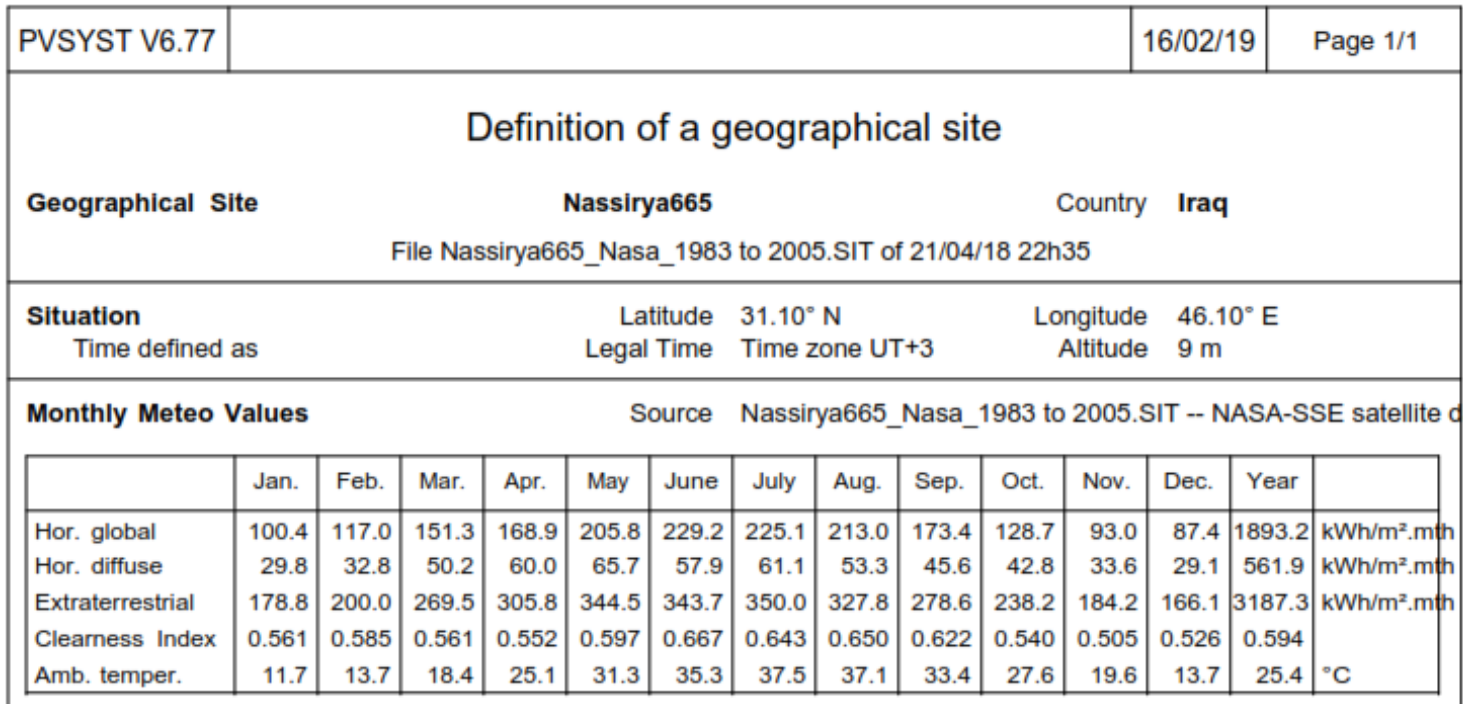

Solar paths at Nassirya665, (Lat. $31.1000^{\circ} \mathrm{N}$, long. $46.1000^{\circ} \mathrm{E}$, alt. $9 \mathrm{~m}$ ) - Legal Time

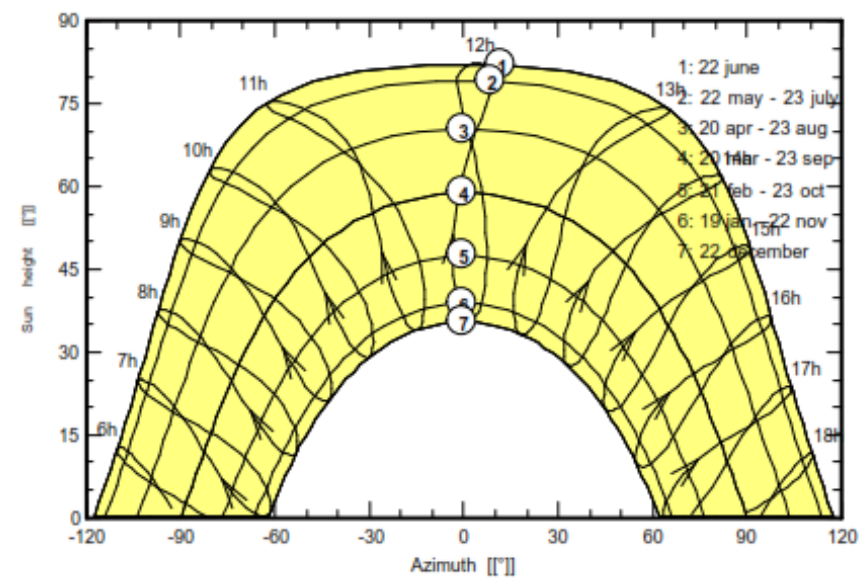

Figure 19. Shows solar paths of Nasiriya city 
The orientation and tilt of the photovoltaic panels determine the amount of light intensity that the panel surface Receives. Variation of the light intensity incident on a solar cell changes all solar cells parameters.

\section{Conclusions}

Cell temperature and solar radiation are significant parameter to optimize the competence of the solar PV cell. A PVsyst model has been enhanced for the solar PV sample which introduced in this paper has created dependent on the essential circuit conditions of sunlight PV cell with counting of physical and ecological parameter. From the outcome, increment in temperature the average of photon age builds accordingly invert saturation current expands quickly and this outcome on decrease in band hole. Thus this prompts to minor changes in current but major changes with voltage. Optimization of these operators is highly critical for efficiency of solar cell the optimum operators make it possible to get the large benefits of solar electricity at a less cost.

Irradiance and Irradiation are related to solar components. As the solar insolation keeps on changing through tout the day similarity I-V and P-V characteristics varies. Temperature acts like a negative factor affecting solar cell performance. Therefore solar cells give their full performance on cold and sunny days rather on hot and sunny weather.

It's shown from this investigation that, it is very successful to build a solar photovoltaic system for al-Nasiriya city that's due its environmental representation and geographical position.

\section{Acknowledgements}

This research was supported/partially by university of Thi-Qar, Engineering collage well as we are very grateful to the Experts from Department of Environmental Sciences in the Nasiriya city who provided insight and expertise also essicial data that greatly assisted the research.

\section{REFERENCES}

[1] Dicks, A. and Rand, D.A.J., 2018. Fuel cell systems explained. Wiley.

[2] J. Phys. Chem. C, 2009, 113 (16), pp 6663-6672.

[3] Prasad, R. M., \& Krishnamoorthy, A. (2018). Design, construction, testing and performance of split power solar source using mirror photovoltaic glass for electric vehicles. Energy, 145, 374-387.

[4] Fereidooni, M., Mostafaeipour, A., Kalantar, V., \& Goudarzi, H. (2018). A comprehensive evaluation of hydrogen production from photovoltaic power station. Renewable and Sustainable Energy Reviews, 82, 415-423.

[5] Jakica, N. (2018). State-of-the-art review of solar design tools and methods for assessing daylighting and solar potential for building-integrated photovoltaics. Renewable and Sustainable Energy Reviews, 81, 1296-1328.

[6] Quansah, D. A., Adaramola, M. S., Appiah, G. K., \& Edwin, I. A. (2017). Performance analysis of different grid-connected solar photovoltaic (PV) system technologies with combined capacity of $20 \mathrm{~kW}$ located in humid tropical climate. International Journal of Hydrogen Energy, 42(7), 4626-4635.

[7] Raugei, M., Sgouridis, S., Murphy, D., Fthenakis, V., Frischknecht, R., Breyer, C., \& Csala, D. (2017). Energy Return on Energy Invested (ERoEI) for photovoltaic solar systems in regions of moderate insolation: A comprehensive response. Energy Policy, 102, 377-384.

[8] Poulek, V., Matuška, T., Libra, M., Kachalouski, E., \& Sedláček, J. (2018). Influence of increased temperature on energy production of roof integrated PV panels. Energy and Buildings, 166, 418-425.

[9] Babatunde, A. A., Abbasoglu, S., \& Senol, M. (2018). Analysis of the impact of dust, tilt angle and orientation on performance of PV Plants. Renewable and Sustainable Energy Reviews, 90, 1017-1026.

[10] Dey, S., Lakshmanan, M. K., \& Pesala, B. (2018). Optimal solar tree design for increased flexibility in seasonal energy extraction. Renewable Energy, 125, 1038-1048.

[11] Kaushika, N. D., Mishra, A., \& Rai, A. K. (2018). Electrical Characteristics of Solar Cells. In Solar Photovoltaics (pp. 73-80). Springer, Cham.

[12] Zhao, Y., Ball, R., Mosesian, J., de Palma, J. F., \& Lehman, B. (2015). Graph-based semi-supervised learning for fault detection and classification in solar photovoltaic arrays. IEEE Transactions on Power Electronics, 30(5), 2848-2858. 